\title{
In Memoriam: Professor Edward C. Luck (1948-2021)
}

\author{
Alex J. Bellamy \\ Professor of Peace and Conflict Studies, School of Political Science and \\ International Studies, University of Queensland, Brisbane, Australia \\ a.bellamy@uq.edu.au
}

On a warm summer's day in Berlin in 2008, the UN's Secretary-General Ban Ki-moon delivered one of the defining speeches of his term. The SecretaryGeneral spoke of his 'deep and enduring' personal commitment to the 'Responsibility to Protect' - or RtoP for short. He clarified that the principle rested on three pillars of responsibility, that it was a friend not an enemy of sovereignty, and that his strategy for implementation would be narrow but deep.

In a few short paragraphs, Ban had defined a challenging new principle with clarity, assuaged concerns raised by many Member States, and set out a bold agenda for action on the prevention of atrocity crimes and protection of vulnerable populations. This vision unleashed an avalanche of activism. The following year, the UN General Assembly adopted a resolution confirming its intention to consider implementation of RtoP. Every year since, the Assembly has received and debated a report on that subject by the Secretary-General. In the three years prior to 2008 , the UN Security Council had referenced RtoP only three times, in the three years after 2008 it referenced the principle nine times; today, that figure stands at ninety-one. In Geneva, it took the Human Rights Council until March 2008 to mention RtoP at all. Since Ban's speech, it has passed fifty-one resolutions referencing RtoP.

Standing in the wings that day was the architect of the Secretary-General's campaign, the brilliant scholar-practitioner, Edward Luck, renowned for his astute political judgment and unfailing generosity of spirit. His untimely passing at the age of 72 is a source of great sorrow for his friends and colleagues, but in particular for those that mattered most of all to him, his beloved family. His enduring legacy is a United Nations and global community of scholars, activists, and practitioners more committed and better prepared to protect vulnerable populations from serious harm than they were when he found them. Through long years on quiet yet unstinting service, often unrecognized and 
unrewarded, Ed shaped a global agenda for human protection and translated his bold ideas into practices that made a difference and will continue making a difference into the future.

Ed was educated at Dartmouth College and then Columbia University, where he earned a string of qualifications, including his Masters of International Affairs and PhD. Even then he had an eye for what was important, not what was fashionable, developing an expertise on Soviet politics and foreign policy and with it a keen sense of the pluralism of international political life that served him well at the United Nations. In almost everything he did, Ed was ahead of his time. RtoP was not the only aspect human protection he developed and advanced. Ed worked on Security Council veto restraint a decade before it was popular, crafted a global agenda for the protection of children in armed conflict, supported work on the prevention of sexual violence in armed conflict, and was architect of the UN's first counter-terrorism strategy.

He was president and CEO of the UN Association of the US from 1984 to 1994, in which capacity he played a crucial role in engaging both Democrats and Republicans. Between 1995 and 1997, Ed helped spearhead management reforms at the UN as a Senior Consultant to the Department of Administration and Management and as a staff director of the General Assembly's OpenEnded High-Level Working Group on the Strengthening of the United Nations System. In that capacity, Ed led the drafting of Security Council reform proposals put forward by President of the General Assembly Razali Ismail in 1997, which included a plan to expand the Council's membership and discourage the use of the veto. Subsequently, he continued to serve the UN as a senior consultant working on issues such as counter-terrorism, the protection of children in armed conflict, and institutional reform. Ed drafted the initial reports of the UN Secretary-General's Special Representative for Children and Armed Conflict in 1997 and 1998, setting out a bold new agenda of work on the protection of children. He helped draft Kofi Annan's 1997 reform package, leading work on the sections on peace and security and on structure of the Secretary-General's Office, and helped draft the UN Secretary-General's first counter-terrorism strategy. In 2008, he was appointed as the SecretaryGeneral's first Special Adviser on the Responsibility to Protect, and it was in this role that he shaped the principle into one that could command international respect and, more importantly, direct its practice. His work with the UN continued long after stepping down from that role, however, and in 2017-2018 he led evaluations of the work of the Special Representatives of the SecretaryGeneral on Children and Armed Conflict and on Sexual Violence in Conflict, and on Violence Against Children. 
Ed was also a gifted teacher and prodigious writer. He was Founder and Executive Director of the New York University/Princeton Center for the Study of International Organization from 1998-2001, before returning to his alma mater, Columbia University in 2001 as Professor of Practice in International and Public Affairs and was appointed Arnold A. Saltzman Professor of Professional Practice in International and Public Affairs in 2012. He was also Dean of the Kroc School of Peace Studies at the University of San Diego for a period as well as teaching at Princeton University (1999-2000) and Sciences Po in Paris (2003-2004). From 2007 until 2011 he was Senior Vice President and Director of Studies of the International Peace Institute. He wrote and edited six books. His 2006 book - UNSecurity Council:Practice and Promise (Routledge)remains the most insightful single-authored book yet on that most important of institutions. His final book, fittingly, reflected on the responsibility to protect principle he helped develop, and received plaudits from his former boss Ban Ki-moon as well as from Gareth Evans. In both of these books, he brought the sort of wisdom and insight to our understanding of the UN and multilateralism that comes only from deep reflection and experience, insights that will go on educating and inspiring as new students read his work.

Thoughtful, modest, and self-effacing, there was always more going on beneath the surface than was apparent above it, agendas to improve multilateralism and fortify human protection being crafted and deftly manoeuvred through the UN's often turbulent politics. For example, from 2003, Ed organized and ran a workshop to help incoming and current members of the Security Council become effective members of the council. In his years as the SecretaryGeneral's Special Adviser on RtoP, he actively sought out the principle's loudest critics, intent on understanding their objections, winning their confidence, and broadening and deepening consensus. Why did he use the acronym 'RtoP' and not the more popular $\mathrm{R}_{2} \mathrm{P}$ ? Simple, Ed explained - in Spanish ' $\mathrm{R}_{2} \mathrm{P}$ ' translates as the meaningless phrase 'R-dos-P'. If the principle had any hope of surviving in the global institution it would need a shorthand the UN's translators could make sense of. Over long hours of careful dialogue and deliberation, for which he wasn't compensated, Ed developed a keen understanding of why governments might be resistant to RtoP and a strategy for moving from promise to practice with the backing of the largest number of governments possible. It is no coincide that the principle's journey from promise to practice coincided with Ed's tenure as the Secretary-General's special adviser. Ed always had a keen understanding of political reality and cool sense of pragmatism, but he also had a fierce determination to leave the world in a better state than he found it. He understood that few things were more important or more difficult to achieve than turning the tide of human suffering caused by war and 
atrocities. He continued to work tirelessly to promote, advance, and innovate on the responsibility to protect developing, with his wife Dana Zaret Luck, a highly-regarded psychologist, a new concept of the individual responsibility to protect. Ed led from the front and gave selflessly of his own time, joining the advisory boards of centres in New York and Australia as well as this journal, and devoting long hours to helping students researching the principle, activists promoting it, and diplomats trying to navigate with it.

In the hundreds of messages of sympathy and condolence posted online, the same words appear again and again: 'he was always so kind' wrote one civil society activist, 'a kind, generous colleague' wrote a UN official, 'such a kind colleague who was always willing to share knowledge and listen to junior colleagues' wrote another former UN official, a 'lovely and supportive colleague. And such a brilliant mind', one of his colleagues at Columbia wrote, 'a wonderful professor, brilliant colleague and kind mentor' wrote one of his former students. Allan Rock, a former Canadian Attorney-General who was Canada's ambassador to the UN at the time RtoP was negotiated, remembered 'Ed had such a depth of knowledge about the UN and its complexities, such vast experience in international affairs, and such a deep commitment to peace and progress for the world. Beyond all of that, Ed had a kind heart and always an open hand, willing to help and provide advice for those who needed his wise and insightful counsel'. Kindness. Generosity. Warmth. These were Ed's calling cards.

Ed had a simple benchmark for assessing the relative merits of UN secretaries-general: did they leave the office of Secretary-General stronger than they found it? There is no surprise that one he rated most highly in that respect was a Secretary-General many others forget, Javier Perez de Cuellar. As he saw it, de Cuellar had navigated the organization through the choppiest of geopolitical waters and left it stronger as a result. Ed was like that. He left us all stronger than he found us. He will be sorely missed. 